Inflation of a splint to $40 \mathrm{~mm}$. $\mathrm{Hg}$ caused a marked reduction In blood flow in the limb in all subjects. Complete cessation of blood flow in the limb occurred in six subjects, and a reduction in blood flow to levels between 0.2 and $0.9 \mathrm{ml}$./ $100 \mathrm{ml}$. tissue $/ \mathrm{min}$. occurred in seven.

Inflation of a splint to $30 \mathrm{~mm}$. $\mathrm{Hg}$ caused a similar but less pronounced reduction in blood flow.

Raising the limb above heart level, combined with splintInflation, still further reduced the blood flow, resulting in complete cessation of the flow in five out of six subjects.

A theoretical explanation of these findings and some implications concerning the use of inflatable splints for the emergency treatment of fractures are discussed.

I am grateful to Mr. J. Sadler for valuable technical assistance, to Professor G. A. Smart for allowing access to patients under his care, and to Professor J. W. Thompson and the late Professor E. A. Pask for advice and assistance.
Requests for reprints should be addressed to Dr. H Ashton, Department of Pharmacology, The Medical School, University of Newcastle upon Tyne.

\section{REFERENCES}

Ashton, H. (1960). "Critical Closing Pressure in Man." D.M. Thesis, University of Oxford.

(1962a). Clin. Sci., 22, 79.

- (1962a). Clin. Sci., 22, 79.

二 (1962b). Ibid. med. Bull., 19, 149

Burton, A. C. (1951). Amer. F. Physiol., 164, 319.

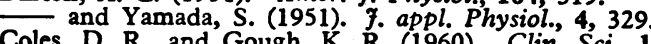

Coles, D. R., and Gough, K. R. (1960). Clin. Sci., 19, 587

Gaskell, P., and Krisman, A. M. (1958). Circulat. Res., 6, 461.

Greenfield, A. D. M., Whitney, R. J., and Mowbray, J. F. (1963). Brit. med. Bull., 19, 101.

Holling, H. E., and Verel, D. (1957). Clin. Sci., 16, 197.

Jennings, A. M. C. (1964). Brit. 7. Anaesth., 36, 683.

Kelly, A. P., and Fox, J. I. (1963). Arch. environm. Hlth, 7, 282

Pask, E. A.' (1965). Personal communication.

Roddie, I. C., and Shepherd, J. T. (1957). 尹. Physiol. (Lond.), 136, 498

Thomson, A. E., and Doupe, J. (1949). Canad. J. Res., 27, 72.

alder, D. M. (1965). Personal communication.

Whitney, R. J. (1953). F. Physiol. (Lond.), 121, 1

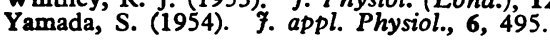

\title{
Renin Secretion by the Denervated Kidney
}

\author{
EDMUND J. LEWIS,* M.D.; M. DONALD BLAUFOX, $†$ M.D., PH.D. ; ROGER B. HICKLER; $\ddagger$ M.D.
}

Brit. med. F., 1966, 2, 1430-1431

The mechanisms regulating renin secretion by the kidney are conjectural at present. The demonstration of renin in the cells of the juxtaglomerular apparatus (Edelman and Hartroft, 1961) and the anatomical evidence that these cells are innervated (Barajas, 1964) have led some investigators to suggest that the sympathetic nervous system may play a part in controlling the renin-angiotensin-aldosterone system (Wathen et al., 1965; Gordon et al., 1966).

In man the change of posture from the recumbent to the upright position is associated with an elevation of the peripheral venous renin activity (Conn et al., 1965). This suggests increased renin secretion by the kidney.

We have studied three renal homograft recipients in order to observe the effect of renal denervation upon the postural renin response.

\section{Methods}

Case Material.-Two subjects who had previously donated a kidney served as normal controls. Three renal transplant recipients made up the experimental group (see Table I).

Procedure.-All of the patients were on an ad lib. salt intake before the study. Blood samples were drawn after each subject had been erect and active for four hours and again after four hours of recumbency. Peripheral venous renin activity was determined by Hickler's modification (Blaufox et al., 1966) of the method of Boucher et al. (1964). This modification differs from the originally described method in so far as (1) after incubation the resin-containing peptide is washed and eluted by the batch method, no column being used, and (2) the elutions are collected in a cold flask and dried rapidly on a flash

- Research Fellow, Renal Laboratory, Peter Bent Brigham Hospital, Boston, Massachusetts. Present address: Kidney Disease Branch, Division of Chronic Diseases, U.S. Public Health Service, Washington, D.C.

t Research Fellow, Renal Laboratory, Peter Bent Brigham Hospital, Boston, Massachusetts. Present address: Albert Einstein College of Medicine, Bronx, New York.

¥ Assistant Professor, Harvard Medical School ; Director, Hypertension Laboratory, Peter Bent Brigham Hospital, Boston, Massachusetts. evaporator. No acetic acid is used in the collection flask. The result is therefore a product which does not need sublimation before bioassay. The results of the investigation are given in Table II.

\begin{tabular}{|c|c|c|c|c|c|c|}
\hline \multirow{2}{*}{$\begin{array}{l}\text { Case } \\
\text { No. }\end{array}$} & BUN & $\mathrm{Cr}_{3}$ & $\mathrm{C}_{\mathrm{cr}}$ & $\mathrm{U}_{\mathrm{Na}}$ & \multirow{2}{*}{ Urinalysis } & \multirow{2}{*}{ Remarks } \\
\hline & \multicolumn{2}{|c|}{ (mg./100 ml.) } & $(\mathrm{ml} . / \mathrm{min})$. & $\mathrm{mEq} / 24 \mathrm{hr}$ & & \\
\hline 1 & 17 & 1.9 & 67 & 270 & Negative & $\begin{array}{l}\text { Identical twins; } \\
10 \text { months post }\end{array}$ \\
\hline 2 & 18 & $1 \cdot 2$ & 60 & 150 & . & $\begin{array}{l}\text { transplant } \\
\text { Brother donor; } \\
2 \text { months post- }\end{array}$ \\
\hline 3 & 23 & 1.5 & 93 & 200 & & $\begin{array}{l}\text { transplant } \\
\text { Brother donor; } \\
11 \text { months post- } \\
\text { transplant; } \\
\text { maintained on } \\
500 \text { mg. Aldo- } \\
\text { met* daily }\end{array}$ \\
\hline
\end{tabular}

BUN $=$ Blood urea nitrogen. $\mathbf{C r}_{8}=$ Serum creatinine. $\mathrm{C}_{\mathrm{wr}}=$ Creatinine clearance. $\mathrm{U}_{\mathrm{Na}}=$ Sodium output for the 24 hours preceding the study.

- Aldomet (methyldopa).

TABlB II.-Results. Peripheral Venous Renin Activity Levels are Recorded as Nanograms Angiotensin II Evolved per $100 \mathrm{ml}$. Plasma per 3-hour Incubation

\begin{tabular}{|c|c|c|c|c|}
\hline & \multicolumn{2}{|c|}{ Supine } & \multicolumn{2}{|c|}{ Erect } \\
\hline & $\begin{array}{c}\text { B.P. } \\
\text { (mm. } \text { Hg })\end{array}$ & $\begin{array}{c}\text { Renin } \\
\text { (ng. A/100 ml.) }\end{array}$ & $\underset{(\mathrm{mm} \cdot \mathbf{H g})}{\text { B.P. }}$ & $\begin{array}{c}\text { Renin } \\
\text { (ng. } \mathrm{A} / 100 \mathrm{ml} \text {.) }\end{array}$ \\
\hline Controls $\left\{\begin{array}{l}\mathrm{A} \\
\mathrm{B}\end{array}\right.$ & $\begin{array}{l}134 / 88 \\
130 / 82\end{array}$ & $\begin{array}{l}123 \\
127\end{array}$ & $\begin{array}{l}118 / 80 \\
105 / 75\end{array}$ & $\begin{array}{l}292 \\
426\end{array}$ \\
\hline Patients $\left\{\begin{array}{l}1 \\
2 \\
3\end{array}\right.$ & $\begin{array}{l}132 / 80 \\
130 / 85 \\
164 / 110\end{array}$ & $\begin{array}{r}36 \\
342 \\
414\end{array}$ & $\begin{array}{l}124 / 92 \\
136 / 90 \\
130 / 105\end{array}$ & $\begin{array}{r}317 \\
677 \\
2,030\end{array}$ \\
\hline
\end{tabular}

Ten recovery experiments with Hypertensin-Ciba (angiotensin amide) resulted in recovery of $76-100 \%$ of the known. Mean recovery in these experiments was $90 \% \pm 7 \%$ (S.D.). Fifty duplicate samples resulted in a mean difference of $10.4 \%$ in reproducibility of the renin activity measured in peripheral venous blood. 


\section{Discussion}

The transplanted human kidney satisfies the criteria for denervation put forth by Quinby (1916) and emphasized by Bricker et al. (1958). Earlier reports have indicated that the sympathetic nervous system may play a part in the regulation of the secretion of renin by the cells of the juxtaglomerular apparatus. The renal nerves (Taquini et al., 1964 ; Tobian et al., 1965) and circulating catecholamines (Gordon et al., 1966) have both been implicated as mediators of this regulatory mechanism. The present findings indicate that the normal "renin response" seen with postural change apparently remains intact after denervation of the kidney. Previous studies have cast doubt upon the contention that circulating catecholamines stimulate renin secretion. Laragh et al. (1960) were unable to demonstrate elevation of the aldosterone secretory rate with infusion of catecholamines. This is indirect evidence that renin secretion did not rise in his subjects. Wathen et al. (1965) were not able to stimulate renin release in dogs with intravenous catecholamine administration, though perfusion of catecholamines direct into the renal artery did increase renin secretion.

Studies performed upon persons with idiopathic orthostatic hypotension who do not display the normal orthostatic increase in sympathetic activity have suggested that low circulatory catecholamine levels do play a part in the abnormal renin secretory pattern seen in these patients (Gordon et al., 1966). Hall and Hökfelt (1966) confirmed these findings; however, they could not reproduce this phenomenon in normal subjects given adrenergic blocking agents.

Conflicting experimental findings must leave the question of sympathetic mediation of the renin-angiotensin-aldosterone system an open one. Lewis et al. (1966) have previously shown that normal sodium-regulating mechanisms persist after human renal denervation and transplantation.

The present results support the concept that homoeostatic mechanisms involving renin secretion are intact after renal denervation. While this finding does not disprove the existence of some association between the sympathetic nervous system and the renin-angiotensin-aldosterone system, it suggests that other mechanisms are also operative.

\section{Summary}

Peripheral venous renin levels were measured in three homotransplant patients in the upright and recumbent positions. The normal pattern of elevation of the renin level in the upright position and depression in the recumbent position was seen. It is concluded that a mechanism independent of the renal nerves is operative in regulating the postural change in renin secretion by the kidney.

Dr. Hickler is a Career Development Awardee, U.S. Public Health Service, 5K3-HE-14903. Dr. Lewis performed his work during the tenure of a Postdoctoral Fellowship awarded by the National Heart Institute (NIH, U.S. Public Health Service). Dr. Blaufox performed this work during the tenure of an Advanced Research Fellowship of the American Heart Association.

\section{REFERENCES}

Barajas, L. (1964). Lab. Invest., 13, 916.

Blaufox, M. D Birbari A Hickler, R. and Merrill, J. P. (1966). New Engl. f. Med. To be published.

Boucher, R., Veyrat, R., de Champlain, J., and Genest, J. (1964). Can. med. Ass. f., 90, 194.

Bricker, N. S., Straffon, R. A., Mahoney, E. P., and Merrill, J. P. (1958) f. clin. Invest., 37, 185 .

Conn, J. W., Rovner, D. R., and Cohen, E. L. (1965). Ann. intern. Med., 63, 266.

Edelman, R., and Hartroft, P. M. (1961). Circulat. Res., 9, 1069.

Gordon, R. D., Kuchel, O., Island, D. P., and Liddle, G. W. (1966). 7. clin. Invest., 45, 1016.

Hall, K., and Hökfelt, B. (1966). Acta med. scand., 179, Suppl. No. 445, p. 397.

Laragh, J. H., Angers, M., Kelly, W. G., and Lieberman, S. (1960).

Lewis, E., Blaufox, M. D., Jagger, P., Lauler, D., Qureshi, E., and Merrill, J. P. (1966).

Quinby, W. C. (1916). f. exp. Med., 23, 535.

Taquini, A. C., Blaquier, P., and Taquini, A. C., jun. (1964). Canad. med. Ass. F., 90, 210.

Tobian, L., Braden, M., and Maney, J. (1965). Fed. Proc., 24, 405.

Wathen, R. L., Kingsbury, W. S., Stouder, D. A., Schneider, E. G., and Rostorfer, H. H. (1965). Amer. F. Physiol., 209, 1012.

\title{
Low-dosage Oral Ethynodiol Diacetate Tablets for Long-term Contraception in Indian Women
}

\author{
PRABHAKER N. SHAH,* M.D., F.C.P.S.
}

From field studies in Puerto Rico, Mexico, and Ceylon it has become evident that, contrary to all predictions by the experts, the poorly educated women of low socio-economic status accept oral contraception enthusiastically and successfully (Rice-Wray, 1957 ; Rice-Wray et al., 1965 ; Chinnatamby, 1965 ; Rao, 1965). In that respect, as I reported earlier (Shah, 1965, 1966), Indian women belonging to this class of society are no different from their counterparts in other parts of the world. In fact, once these women know that an oral "pill " is available, it is difficult if not impossible to make them use any other method of birthspacing.

Since the contraceptive efficiency of the various synthetic progestogens in different geographical populations is no longer in dispute, current research is directed towards finding an oral contraceptive that would have a low incidence of side-reactions

- Department of Endocrinology, Indian Cancer Research Centre, Parel, Bombay, India. and a good cyclic control in each population, and towards assessment of the lowest effective dosage for each compound for successful contraception. Such low-dosage tablet, so far as developing countries like India are concerned, would have two added advantages: (1) reduce the cost of the pill, and (2) minimize its inhibiting effect on lactation in women in whom breast-feeding is a necessity for reasons of economy. The purpose of this paper is to report a few aspects arising out of our experience related to the administration of low-dosage ethynodiol diacetate in "combined" or "sequential" schedules for contraception in Indian women.

\section{Present Series}

A total of 380 fertile women aged 18 to 35 , with an average age of 24.2 years, participated in the trial. Analysis of the data of these women indicated that $62 \%$ were illiterate or had had 